Metallophysics and Advanced Technologies

металофіз. новітні технол.

Metallofiz. Noveishie Tekhnol.

2021, vol. 43, No. 3, pp. 383-398

https://doi.org/10.15407/mfint.43.03.0383

Reprints available directly from the publisher

\title{
PHASE TRANSFORMATIONS
}

PACS numbers: 42.62.Be, 42.62.Cf, 62.20.fg, 81.20.Vj, 81.30.Kf

\section{Laser Welding of Ti-Ni Shape Memory Alloy for Medical Application}

\author{
V. Shelyagin, A. Bernatskyi, O. Siora, S. Kedrovskyi, ${ }^{*, * *}$, Yu. Koval ${ }^{*, * * *}$, \\ V. Slipchenko", V. Filatova", and G. Firstov" \\ E.O. Paton Electric Welding Institute, N.A.S. of Ukraine, \\ 11 Kazymyr Malevych Str., \\ UA-03150 Kyiv, Ukraine \\ "G.V.Kurdyumov Institute for Metal Physics, N.A.S. of Ukraine, \\ 36 Academician Vernadsky Blvd., \\ UA-03142 Kyiv, Ukraine \\ **National Technical University of Ukraine \\ 'Igor Sikorsky Kyiv Polytechnic Institute', \\ 37 Peremohy Ave., \\ UA-03056 Kyiv, Ukraine
}

The work is devoted to investigations of laser welding of rolled metal of a medical functional $\mathrm{Ti}-\mathrm{Ni}$ system alloy. On the basis of the analysis of literary sources and the results of own investigations of the influence of laser welding parameters on functional characteristics of $\mathrm{Ti}-\mathrm{Ni}$ shape memory alloy, the challenging directions of the further investigations are established. According to the results of the investigations of welds microstructure, concentration dependence of absolute values of recovery deformation during measurement of the shape memory effect, and investigations of phase transitions, it is established that the processes, occurring in welding zone, affect not only the strength of a joint, but also the parameters of martensitic transformation. As established, due to laser radiation and subsequent recrystallization of material in the weld area, the feasibility of shape recovery by the material of the weld body is saved, but characteristic temperatures of direct and reverse martensitic transformations grow up. The direct martensitic transformation in the region of welded joints is observed in the temperature range

Corresponding author: Heorhiy Serhiyovych Firstov

E-mail: yuri.firstov@gmail.com

Citation: V. Shelyagin, A. Bernatskyi, O. Siora, S. Kedrovskyi, Yu. Koval, V. Slipchenko, V. Filatova, and G. Firstov, Laser Welding of Ti-Ni Shape Memory Alloy for Medical Application, Metallofiz. Noveishie Tekhnol., 43, No. 3: 383-398 (2021), DOI: 10.15407/mfint.43.03.0383. 
from $45^{\circ} \mathrm{C}$ to $20^{\circ} \mathrm{C}$. Shape recovery in material of welded joints is observed at temperature range of $60-100^{\circ} \mathrm{C}$. The obtained results allow determining the ranges of values in which it is expedient to optimize the parameters of laser treatment modes.

Key words: shape memory alloys, $\mathrm{Ti}-\mathrm{Ni}$ alloys, laser welding, thermoelastic martensitic transformation, recrystallization.

Дана робота присвячена дослідженням лазерного зварювання прокату функціонального стопу медичного призначення системи Ti-Ni. На основі аналізу літературних джерел та результатів власних досліджень впливу параметрів лазерного зварювання на функціональні характеристики стопу Ti-Ni з ефектом пам'яті форми встановлено перспективні напрями подальших досліджень. За результатами дослідження мікроструктури зварних швів, концентраційної залежності абсолютних величин відновлюваної деформації при вимірюванні ефекту пам'яті форми та дослідження фазових переходів встановлено, що процеси, які мають місце в зоні зварювання, впливають не тільки на міцність з'єднання, а й на параметри мартенситного перетворення. Встановлено, що в результаті дії лазерного випромінювання та подальшої перекристалізації матеріалу в зоні зварного шва можливість відновлення форми матеріалом в тілі шва зберігається, але характерні температури прямого і зворотного мартенситного перетворень зростають. Пряме мартенситне перетворення в області зварних з'єднань спостерігається в інтервалі температур від $45^{\circ} \mathrm{C}$ до $20^{\circ} \mathrm{C}$. Відновлення форми зварних з'єднань спостерігається за температур в межах 60$100^{\circ} \mathrm{C}$. Результати роботи дозволили визначити області значень, в яких доцільно проводити оптимізацію параметрів режимів лазерної обробки.

Ключові слова: стопи з пам'яттю форми, стопи $\mathrm{Ti}-\mathrm{Ni}$, лазерне зварювання, термопружне мартенситне перетворення, рекристалізація.

(Received September 2, 2020)

\section{INTRODUCTION}

In the field of cardiac surgery, solving the problem of conducting operations at the beating heart is of great importance. Already several decades ago, such operations at the heart required its arrest, connection of apparatus for artificial blood circulation, and there were difficulties in restarting the heart after surgery [1-3]. But the developments of recent years in the field of functional materials allowed conducting minimally invasive transcatheter cardiac operations without heart arrest. Special probes guiding through the arteries, can implant artificial aortic valves, stents for vasodilatation, and various other implants. Such operations are the least traumatic, the period of patient's staying in a hospital is shortened and a more rapid recovery is observed [4-7].

In Ukraine, cardiac surgeons conduct operations by installing artificial aortic valves of foreign production. These operations have a very 
high cost is between 5000 and 6000 euros [8]. The price of the valve alone is between 500 and 1000 euros. Thus, for domestic science the urgent task of import substitution is emerging in order to develop and offer a much cheaper analogue of such a valve, which will provide curing of considerably more patients under the same budget financing. To solve this task, it is necessary to develop and organize manufacturing of materials for the valves themselves, to develop the designs and technologies for manufacturing frames of new valves, to develop methods of delivery and installing of these implants. To solve such complex integrated task, it is planned to use resources of a wide range of research subdivisions of different state institutions, and to achieve the desired result in close collaboration between material scientists, designers, technologists and doctors.

This work is devoted to presentation of the results of the first stage of the project, at which the specialists of the E. O. Paton Electric Welding Institute, N.A.S. of Ukraine carried out the technological investigations on laser welding of rolled metal of the experimental alloy of the Ti-Ni system, developed and manufactured by the scientists of the G. V. Kurdyumov Institute for Metal Physics, N.A.S. of Ukraine.

The aim of this work is to establish the challenging directions of the own investigations, based on the analysis of literary sources and the results of investigations of the influence of laser radiation on functional characteristics of $\mathrm{Ti}-\mathrm{Ni}$ shape memory alloy during welding.

\section{ANALYSIS OF SOURCES}

Despite the development of medical technologies, heart valve failures still remain a significant and widespread disease [1-3]. This pathology amounts approximately to $2.5 \%$ in the structure of the general morbidity of population and is characterized by a pronounced age correlation from $0.7 \%$ at the age of $18-44$ years to $13.3 \%$ at 75 years [5]. Along with the tendency of growing percentage of the elderly population in developed countries, this dependence allow predicting an increased significance of heart valve failures as a disease: according to the World Health Organization, in the period from 2000 to 2050, the world's population over the age of 60 will increase more than three times-from 600 million to 2 billion [5]. Among all the widespread valvular heart diseases, aortic stenosis prevails. Its isolated form amounts to $33.9 \%$ of the total number of valve pathologies without taking into account the numerous valve lesions-20.2\% [9]. Similarly to the epidemiology of all the valvular heart diseases, this disease is predominantly of the elderly population: from $2.5 \%$ at the age of 75 , to $8 \%$ at the age of 85 years [7, 9]. Anatomically, aortic stenosis is manifested in the form of narrowing of the aorta in the valve area, which prevents a normal flow of blood, resulting in significant hemo- 
dynamic disturbances.

The worldwide clinical experience in the application of the new technology for interventional treatment of aortic stenosis has largely been gained due to the two fundamentally different systems: CoreValve ${ }^{\circledR}$ (Medtronic, Inc., USA) and Sapien ${ }^{\mathrm{TM}}$ (Edwards LifeSciences, Inc., USA) (Fig. 1) [10]. The Sapien ${ }^{\mathrm{TM}}$ bioprosthesis represents a constrained apparatus made of preserved bovine pericardium, mounted on a cylindrically expanding stent-like supporting frame made of cobalt-chrome alloy. The implantation of the bioprosthesis is carried out in the intraannular position with the help of a transfemoral and transapical cylindrically expanding delivery system. The corresponding success rate of implantation reaches $95.2 \%$ and $92.7 \%$ [11].

An alternative approach to the seamless fixation mechanism is realized in the CoreValve bioprosthetics due to the self-deploying frame of the valve made of superelastic titanium nickelide alloy (nitinol) having a stent-like structure. A constrained apparatus of this prosthesis is made of preserved pork pericardium. There are four main standard sizes of the valve: it has a diameter of $23,26,29$ and $31 \mathrm{~mm}$, corresponding to the diameter of the FC in the range of $18-29 \mathrm{~mm}$. The modern (third) generation of the CoreValve bioprosthesis is implanted in the supraanular position, the main fixation takes place in the FC area due to expanding force created by the valve frame. To improve hemodynamics of the bioprosthesis and to prevent paravalvular regurgitation, the section for blood congestion is also covered with pork pericardium. The results of application of namely the third generation of CoreValve are most widely covered in literature. The success rate of the implantation of the CoreValve bioprosthesis according to different

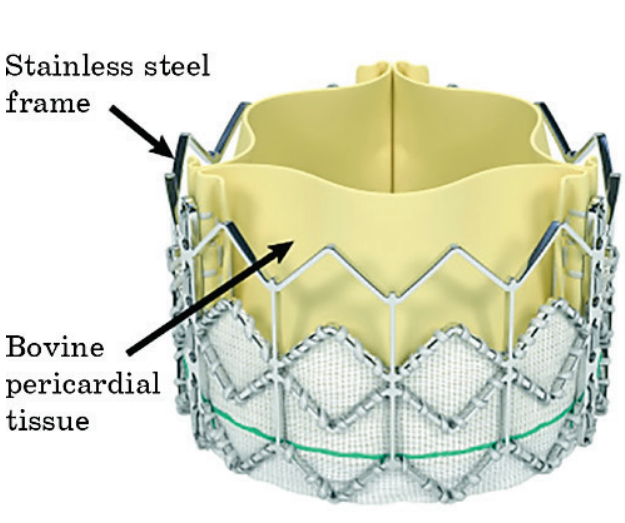

$a$

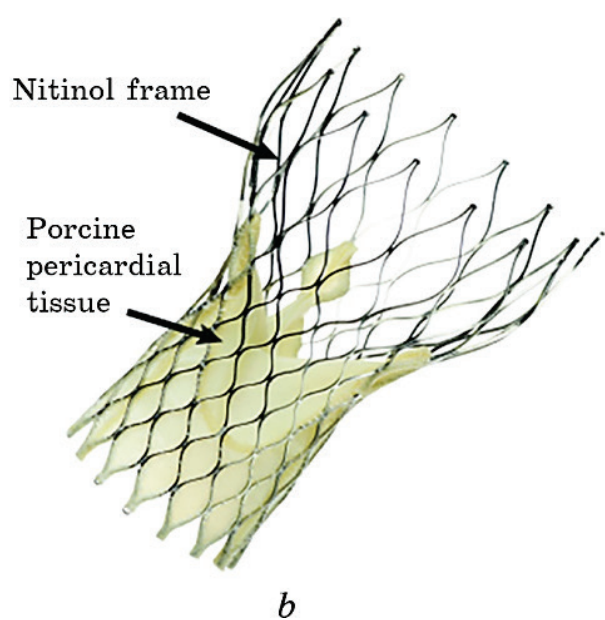

Fig. 1. Transcatheter systems for treatment of aortic stenosis: CoreValve (Medtronic, Inc., USA) (a), Sapien (Edwards LifeSciences, Inc., USA) (b) [10]. 
estimates reaches $\mathbf{9 0 . 5}-\mathbf{9 8 . 0} \%[12,13]$.

Despite the different delivery methods and structural differences between the devices for minimally invasive prosthetics of the aortic valve, the unity of a biomechanical principle of interaction with the surrounding tissues and the base of the structure allows combining them into a conventional general class of seamlessly implanted devices $[1,3,14]$.

Since the first implantation of the self-expanding CoreValve aortic valve bioprosthesis in 2004, three generations of its frame designs have changed [15]. The successful clinical testing of this valve on the one hand and its existing drawbacks on the other determined the development of new devices of the next generation on the basis of this technology attempting to create a 'perfect' prosthesis. Despite the diversity of existing designs of seamlessly implanted prostheses, most of them are made on the basis of one material and has a single principle of fixation in the aorta, as well as a similar principle of structure.

The main factor in the problem of biocompatibility is the compliance of the behaviour of metal alloys with the behaviour of the body tissues. In this regard, one of the main criteria in selecting material for implantation is the likeness of the value of hysteresis and the value of elastic deformation of the implant to the value of hysteresis and elastic properties of the tissues surrounding the implant [16-19]. The regularities of the phenomenon of hysteretic behaviour of mechanical properties of tissues and their delayed reaction to external influences are the fundamental law of the mechanical behaviour of biological systems. Titanium nickelide and the alloys developed on its basis meet the most severe medical and technical requirements specified to the properties of implantation materials [17].

As a rule, the self-expanding stent structures, including frames of prosthesis with a seamless implantation method, are made of titanium nickelide (nitinol), as far as this material has an effect of superelasticity [20]. This effect consists in the ability of interphase austenitemartensite transformation under the action of external forces, due to which the physical and mechanical characteristics of the material represents a hysteresis loop with the corresponding plateau of loading and unloading [16].

The fundamental criterion during development and manufacture of medical products of this material is the operating temperature, since interphase transformations can take place both under the action of external forces as well as under the action of heating/cooling (shape memory effect (SME)). This effect occurs due to reaching a certain temperature which corresponds to the temperature of transformation [18]: $A_{s}$ is the starting temperature of martensite-austenite transformation during heating; $A_{f}$ is the final temperature of martensiteaustenite transformation during heating; $M_{s}$ is the starting tempera- 
ture of austenite-martensite transformation during cooling; $M_{f}$ is the final temperature of austenite-martensite transformation during cooling.

First, the material is in the austenitic state $\sigma A_{f}$, under the action of external force an elastic deformation occurs until the stress of starting martensitic transformation (MP) $\sigma M_{s}$, then the material transfers into the martensitic state $\sigma M_{f}[16]$. During the further unloading, the accumulated deformation is completely returned $\left(\sigma M_{f} \rightarrow \sigma A_{s} \rightarrow \sigma A_{f}\right)$. Moreover, the change in the crystalline lattice of metal occurs. The phase of austenite has a crystalline structure with a cubic lattice $B 2$, which provides a high rigidity of the material (Fig. 2), in the phase of martensite, titanium nickelide molecule has a more flexible 'monoclinic' lattice $B 19$ '.

The temperature required for transition from the state of martensite into austenite during heating is slightly higher than for reverse transformation during cooling, which determines the corresponding hysteresis loop of the shape memory effect [16].

The effect consists in the ability of unloaded material under the action of external stress and change in temperature to accumulate deformation $(10-15 \%)$, reverse either during heating, or in the process of removing external stress (superelastic). The deformation can be ac-

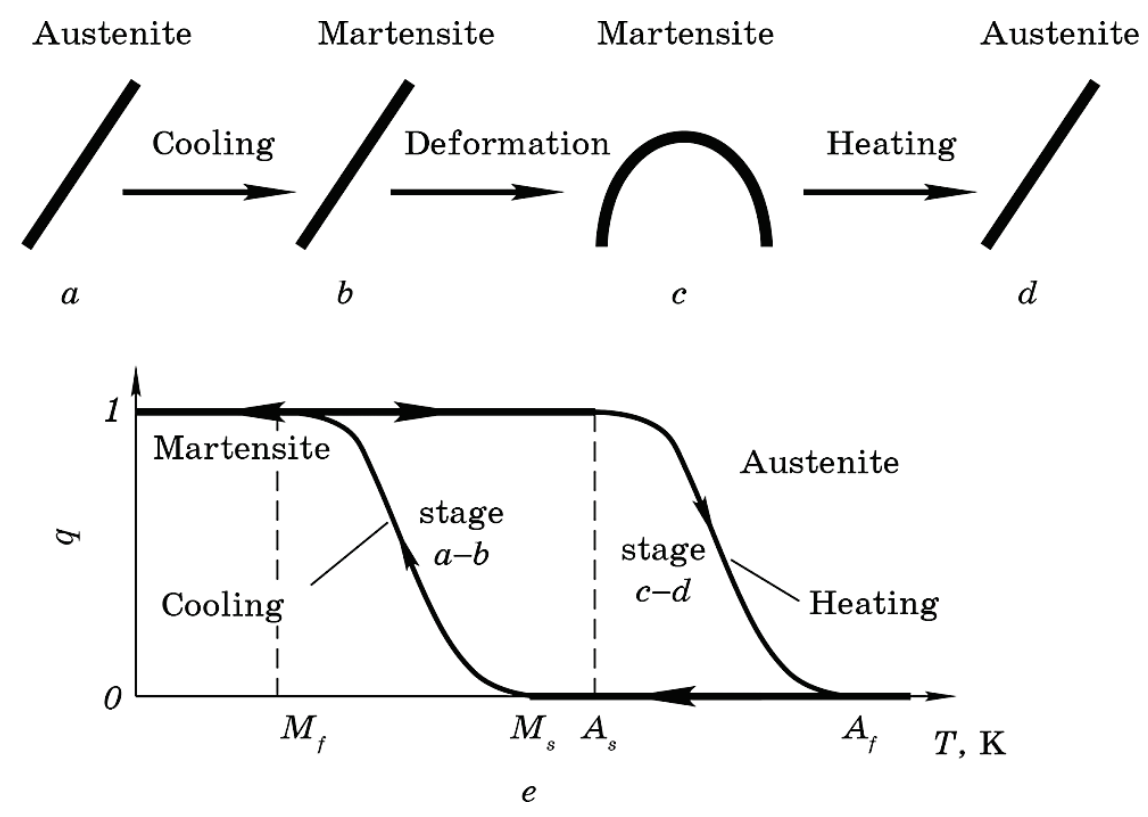

Fig. 2. Scheme of deformation of rod with the shape memory effect $(a-d)$ and dependence of the volume fraction of martensite $q(d)$ on the temperature $T$ [18]. 
cumulated under the active loading, as well as during change in the temperature of the alloy which is under the influence of uniaxial load or shear stress. A typical working cycle for such a material is presented in Fig. 2 [18]. The deformation at the stage $b-c$ (Fig. 2) [18] is accumulated due to reorientation of martensite crystals (effect of martensitic inelasticity) and remains after removal of loads. The shape memory effect is manifested at the stage $c-d$ (Fig. 2), where the material independently restores its shape and can develop significant efforts.

The transformation temperatures are set by the initial ratio of the alloy components, and also by the subsequent heat treatment of the material. Thus, the effects are superelastic and the shape memories are determined by the ratio of transformation temperatures and the environment [21]. For this purpose, in the medicine, the grades of alloy with a nickel content of $48-51 \%$ are used, which provides an opportunity to select a wide range of functional behaviour, which are designed for operation under the temperature of human body of $37^{\circ} \mathrm{C}$.

The main advantage of titanium nickelide implants is the plasticity and ability to restore the original shape during change in the temperature mode [17]. However, any metal is an alien material for the body and, in this regard, the implant will cause the reaction of its tissues. The degree of severity of this reaction is one of the main characteristics of any implantable material. The alloy of nickel and titanium has advantages, as far as on its surface a protective oxide film is formed which considerably raises the degree of its biological inertia and corrosion resistance. An oxide film (titanium dioxide) is spontaneously formed in a few minutes in an oxygen-containing atmosphere, reaching a thickness from 10 to $100 \mathrm{~nm}$, represents a stable ceramic compound, on which plasma proteins, organic and mineralized bone matrix can be precipitated. The grafting ability of nickelide-titanium structures is associated with their interaction with tissues. In animal experiments, it was shown that there is a relationship between the contacting tissue and the nickelide-titanium implant: the joining tissue grows in the pores of the metal structure, gradually filling them and repeating the relief, providing a mechanical fixation at the interphase boundary. With an increase in the duration of titanium nickelide in the body, the compaction of tissue structures in the pores and around the implant is observed [22].

Although the shape memory effect was detected in the Ti-Ni alloy of the equiathomic composition, the further investigations showed that the alloys of non-stoichiometric composition and the alloys alloyed with one or more elements of the periodic system represent an interest (in particular, for using in medicine) [17]. Let us call these alloys the titanium nickelide-based alloys.

The interest to the titanium nickelide system $\mathrm{Ti}-\mathrm{Ni}$ appeared after detection of the shape memory effects in martensitic transformations, 
caused by the need in making the diagram more precise, especially near the equiatomic composition [12-16]. It was established that homogeneous interval of the intermetallic compound $\mathrm{Ti}-\mathrm{Ni}$ is in the range of $49-53$ at. $\%$ of $\mathrm{Ni}$ at a temperature of $800^{\circ} \mathrm{C}$ and $49.5-51$ at. $\%$ of $\mathrm{Ni}$ at a temperature of $400^{\circ} \mathrm{C}$. Beyond the region of homogeneity, the alloy consists mainly of $\mathrm{TiNi}+\mathrm{Ti}_{2} \mathrm{Ni}$ phases during enrichment of its equiatomic composition with titanium and of $\mathrm{TiNi}+\mathrm{TiNi}_{3}$ during its enrichment with nickel. If in the composition of the phase enriched with titanium, there are no discrepancies, than during investigations of compositions enriched with nickel, the results of different authors are noticeably different. Therefore, the study of this problem is the first among the relevant tasks of the whole project.

The design of heart valve frames with a seamless method of fixation is inseparably associated with the technology of their manufacture [18]. This dependence is predetermined on the one hand by the limited range of manufacturers of nitinol (wire, metal sheets, hollow tubes), and on the other hand by the historical aspect of development of transcatheter bioprostheses. The first valves were developed on the basis of the already existing technology of production of selfexpanding stents [19]. In terms of the manufacturing process, there are no fundamental differences between these devices and they can be attributed to a one class.

There are two traditional technologies for stent manufacturing: wire braiding using welded joints, and the method of laser cutting from hollow tubes [23]. The latter method became more widespread in case of manufacture of such structures as valve frame, as far as at a set thickness of the tube, it is possible to vary the width of laser-cut elements.

The diamond cell structure is the base for most of the stent structures [24], in particular for many frames of aortic valve prosthesis with a seamless fixation method. In its turn, each cell consists of beams, the rows of which are joined by connectors. The stent produced using laser, has sharp edges and rough surface [16]. In order to prevent a possible thrombosis and minimize complications, the process of the electrochemical polishing is used, which affects stent mechanical properties due to the change in the shape and area of the beam crosssection. This also affects its service life by eliminating microcracks arising during local overheating of the material. The final stage of stent production is a heat treatment in order to provide the final shape in the expanded state. Thus, under the influence of external forces during packing into the delivery system, the stent is capable of returning to the initial diameter of the tube from which it was made, at the same time accumulating the potential energy sufficient for its independent evolution.

Before manufacturing a stent, its 'pattern' and properties (flexibil- 
ity, rigidity, etc.) are determined using calculations, which account the properties of a material, diameter, width, thickness of separate threads and their mutual spatial arrangement. The typical technological process of manufacturing a stent is the following: producing a tubular billet with set properties, laser cutting of billet and its finishing treatment (electrochemical polishing). Also, at the final stage of manufacturing the product, it is possible to apply medical drugs to its surface, which are intended for a more rapid dissolution of plaque in the vessel.

From all the possible variants of cutting the stent pattern (mechanical, electroerosive, etc.), researchers consider that the laser treatment applying a direct laser cutting is the best variant [24]. Let us note that the additional electrochemical treatment allows eliminating the defects of laser cutting. On the basis of the results of the analysis of the abovementioned data devoted to the review of variants of technologies for manufacturing the frame of the aortic valve, the specialists of the E. O. Paton Electric Welding Institute, N.A.S. of Ukraine were offered to work out the technologies of laser welding and cutting of materials with SME and consider the variants for manufacturing the frame: 1) by laser cutting of tubular billet; 2) by welding a tube rendered from flat billet, and by its subsequent laser cutting; 3) by laser cutting of flat billet, further rolling it into a tubular shape and with the further welding of the produced billet. Specialists of the E. O. Paton Electric Welding Institute, N.A.S. of Ukraine have significant experience in performing technological research in laser welding [25-30].

In this paper, the investigations were carried out which allowed considering the problem of influence of laser welding on the structure and functional properties of a material with SME, developed and produced by the scientists of the G. V. Kurdyumov Institute for Metal Physics, N.A.S. of Ukraine [31-34].

\section{MATERIALS, EQUIPMENT AND METHODS OF INVESTIGATIONS}

As an experimental SME alloy, the specialists of the G. V. Kurdyumov Institute for Metal Physics, N.A.S. of Ukraine produced a rolled metal in the form of strips of $0.5-1.0 \mathrm{~mm}$ thickness of binary composition with 50.6-50.8 at.\% of $\mathrm{Ni}$ and $49.4-49.8$ at.\% of Ti respectively from $30 \mathrm{~g}$ ingots. Such compositions are sensitive to change of the MT parameters under the influence of thermal or thermo-mechanical treatment, and the temperature of $A_{\mathrm{k}}$ is within the range of $36.6-55^{\circ} \mathrm{C}$.

The welding was performed using the fiber laser 'YLR-400-AC' of 'IPG Photonics' (USA) with a wavelength $\lambda=1.07 \mu \mathrm{m}$ and the maximum output power of up to $400 \mathrm{~W}$.

The investigations of the microstructure of welded joints were per- 
formed with the use of integrated optical microscope 'AXIOVERT 40 MAT Carl Zeiss' (Germany) for operation in the reflected light.

The concentration dependence of absolute values of the recovery deformation in the measurement of the SME was determined using the three-point bending method in the specialized installation produced at the G. V. Kurdyumov Institute for Metal Physics, N.A.S. of Ukraine.

The investigations of phase transitions were performed applying the differential scanning calorimetry (DSC) method using the device 'DSC 404 F1 Pegasus' of 'NETZSCH' (Germany).

\section{RESULTS AND DISCUSSION}

The preliminary experimental investigations on laser welding of flat samples of shape memory $\mathrm{Ti}-\mathrm{Ni}$ materials and determining the range of values, in which it is advisable to optimize the parameters of technological modes, were started in the laboratory stand. The criteria for evaluating achievement of the desired result were as follows: sizes of heat-affected-zone (HAZ); geometrical characteristics of the resulting butt join; formation of weld shape meeting the requirements of the standard ISO 13919-1 for the category, not lower than ' $C$ '. The optical fiber was connected to the collimator, which, in its turn, was connected to the input of the custom-made welding head. A lens with a focal length of $160 \mathrm{~mm}$ was installed inside the welding head and focused the laser beam into a spot of $50 \mu \mathrm{m}$ in diameter. At the output of the welding head, the protective nozzle was installed that was used to direct the shielding gas (argon) onto the sample to be welded.

The experimental investigations of laser welding of flat samples of the shape-memory effect materials and determination of the range of values, in which it is advisable to optimize the technological parameters of the welding, were started from making penetration tests in the investigated materials. A photo of the macrostructure in the sample No. 1338.2 of $\mathrm{Ti}+\mathrm{Ni}$ SME material of $0.5 \mathrm{~mm}$ thickness after laser penetration is shown in Fig. 3.

The sample No. 1338.2 was produced with the application of the following values of the parameters of technological modes: laser radiation power $P=200 \mathrm{~W}$, cutting speed $V=700 \mathrm{~mm} / \mathrm{min}$, focal length of the lens $F=160 \mathrm{~mm}$, shielding gas consumption (argon) $Q_{\mathrm{Ar}}=14 \mathrm{l} / \mathrm{min}$, defocusing of the lens $\Delta F=+6 \mathrm{~mm}$. As a result of the experiment on the back side of the sample No.1338.2, the separate punctures were obtained, and the outer appearance of the sample met the abovementioned requirements.

To achieve a complete through melting while performing penetration in the sample No. 1338.3 of Ti + Ni SME material of $0.5 \mathrm{~mm}$ thickness, the laser radiation power was increased to $240 \mathrm{~W}$, preserving all the other values of the technological parameters. 


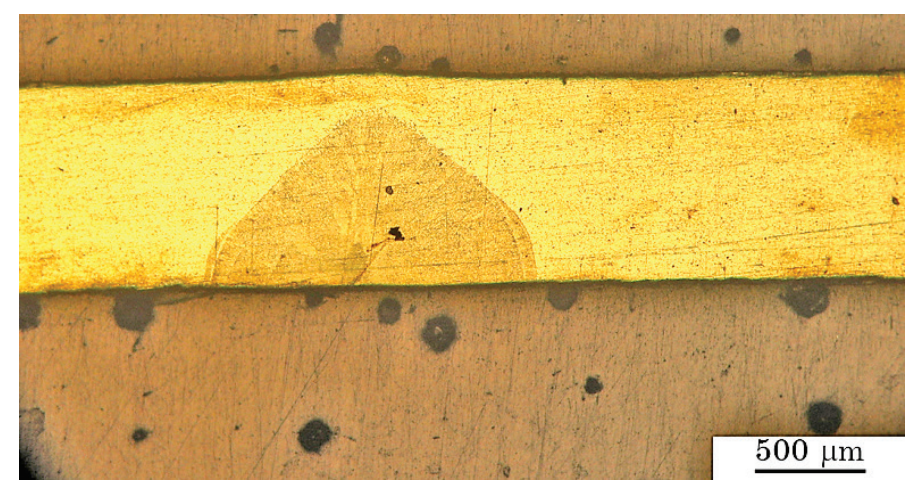

Fig. 3. Photo of the macrostructure of the penetration in the sample No. 1338.2 of $\mathrm{Ti}+\mathrm{Ni}$ SME material of $0.5 \mathrm{~mm}$ thickness after laser penetration tests.

As a result of this experiment in the sample No. 1338.3, a complete penetration of the material was obtained, which allowed increasing the welding speed $V=1000 \mathrm{~mm} / \mathrm{min}$ during welding of the sample No. 1338.4, leaving the other technological parameters at the same level as for the sample No. 1338.3. As a result, a complete penetration was obtained during welding the sample No. 1338.4, which allowed proceeding to the experimental investigations on selection of parameters of laser welding modes of butt welded joints of samples made from with $\mathrm{Ti}+\mathrm{Ni}$ SME material.

The butt-welded joint No. 1338.5 of Ti-Ni SME material of $0.5 \mathrm{~mm}$ thickness (Fig. 4) was welded using the technological parameters similar to the parameters for the sample No.1338.4. The only parameter

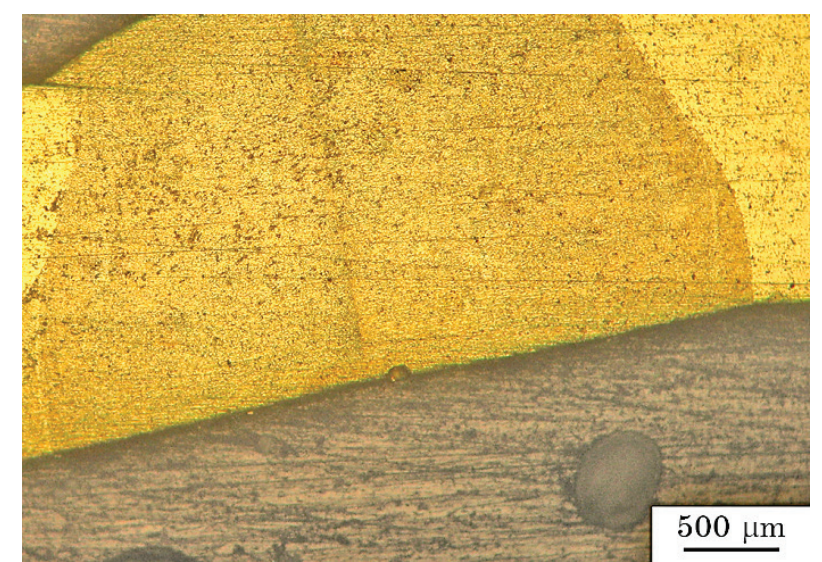

Fig. 4. Photo of the macrostructure in the sample No. 1338.5 of Ti-Ni SME material of $0.5 \mathrm{~mm}$ thickness after laser welding of the joints. 
that was changed is the laser radiation power-it was increased to $260 \mathrm{~W}$ due to the presence of a small gap, formed during a butting of plates after laser cutting (mechanical treatment of edges before welding was not performed).

According to the results of analysis of the cross-section of the macrostructure in the welded joint of the sample No. 1338.5 of the TiNi SME material, it was found that in the sample the recrystallization region of the material is observed caused by thermal action of laser radiation and also a clear boundary between the two plates is present. The micrograins in the recrystallized region are elongated in the direction of heat removal.

The specialists of the G. V. Kurdyumov Institute for Metal Physics, N.A.S. of Ukraine carried out investigations on the degree of laser welding influence on functional peculiarities of the material, temperature of the martensitic transformation, and microstructure of the SME alloy. For this purpose, the weld from the joint No. 1338.5 was cut from the body of the sample and subjected to the further investigations applying DSC and three-point bending for the presence of SME. The investigations of the changes in the functional properties of welded joints of plates made of the alloy of the Ti-Ni system produced by welding with laser radiation, showed that the processes occurring in the heat-affected-zone influence not only the strength of the joint, but also the parameters of the MT. Figure 5 shows the dependence of deflection and recovery of the shape on the temperature. Analysing the dependence of heat flux on the temperature in the samples before and after welding, it was established that in the samples after welding, the temperature intervals of direct and the reverse MT grow in comparison

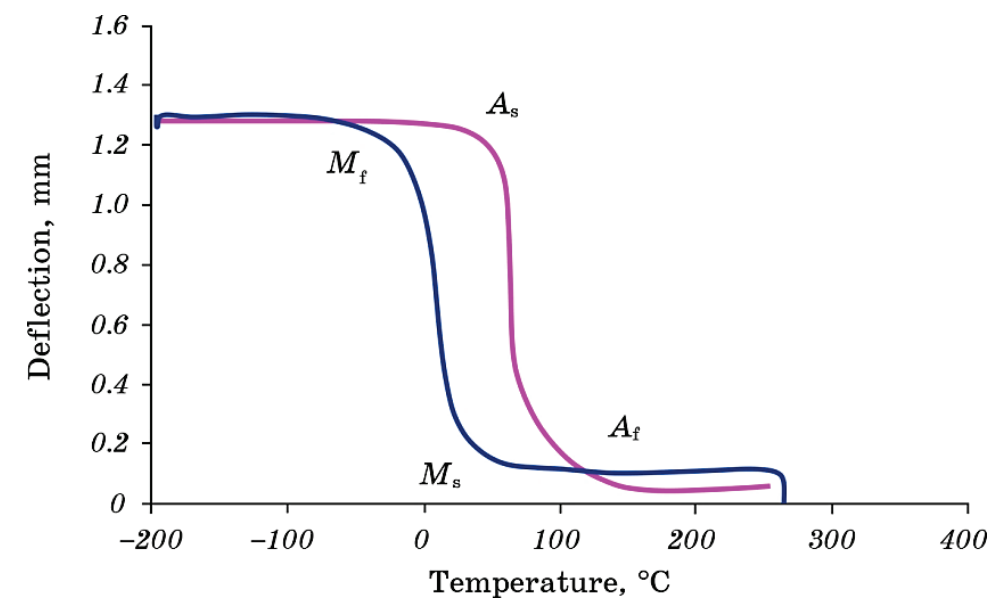

Fig. 5. Dependence of deflection and shape recovery on the temperature of the weld of $\mathrm{Ti}_{49.4} \mathrm{Ni}_{50.6}$ alloy in the sample No. 1338.5. 
with the temperature intervals of the MT in the initial state. The region of direct martensitic transformation is observed in the range from room temperature to $0^{\circ} \mathrm{C}$. The shape recovery was observed from $60^{\circ} \mathrm{C}$ to $100^{\circ} \mathrm{C}$.

Figure 6 shows the results of the DSC analysis. The obtained data testify that as a result of thermal action of laser radiation and subsequent recrystallization of the material in the weld zone, the feasibility of restoring the shape material in the body of the weld were preserved, but the characteristic temperatures of direct and the reverse martensitic transformation increased.

Such a displacement of the temperature intervals of the MT is explained by the change in the chemical or phase composition of the weld zone material as a result of recrystallization process under the action of laser radiation.

This result could be caused by a decrease in the concentration of nickel due to its evaporation or as a result of formation of particles Ti$\mathrm{Ni}_{2}, \mathrm{Ti}_{3} \mathrm{Ni}_{4}$ and others in the weld zone. These temperature characteristics of MT go beyond the medical requirements to the material, however outside the weld zone the functional properties remain unchanged.

To return the characteristic temperatures of the MT of the weld material to the initial values, it is proposed: to optimize laser welding

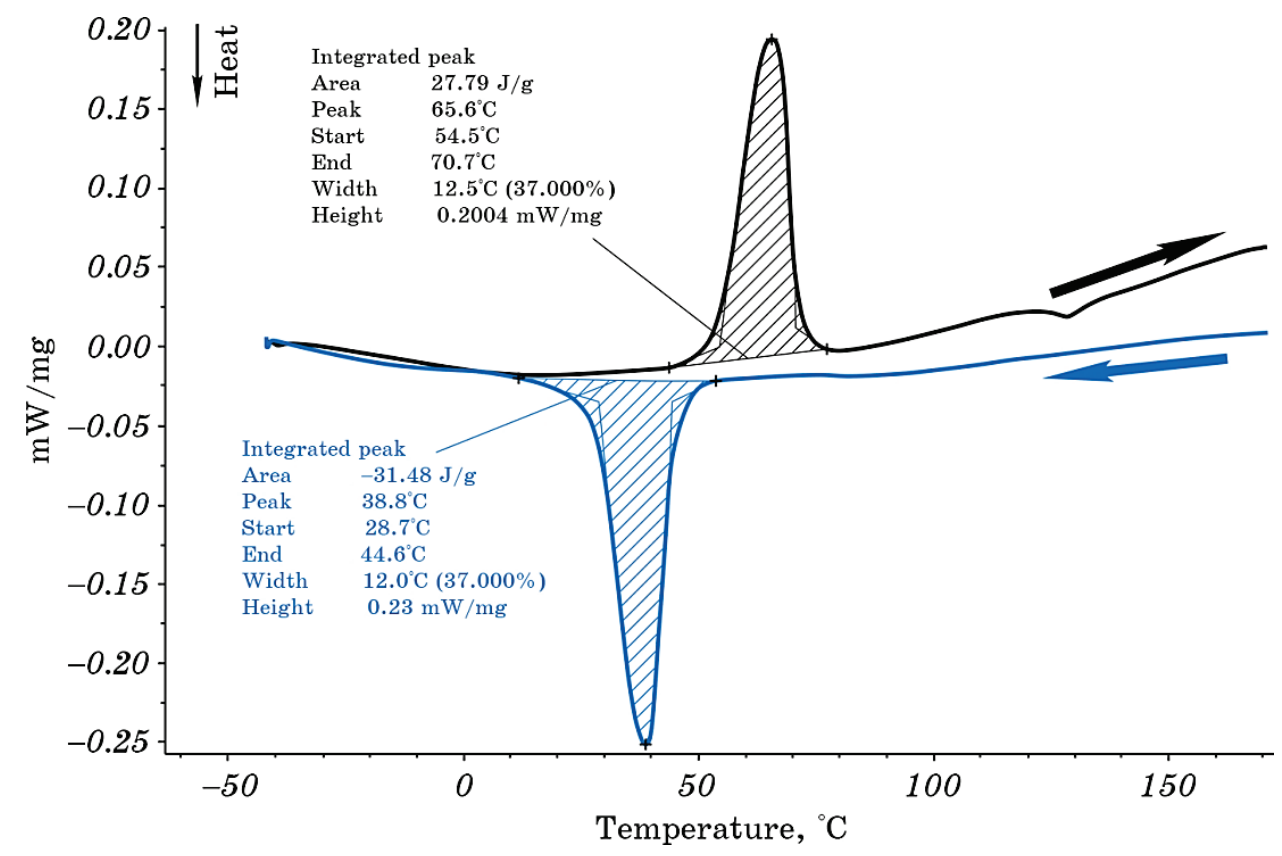

Fig. 6. Results of the DSC analysis of the weld material of the sample No. 1338.5. 
modes of samples of the SME materials, to conduct ultrasonic impact treatment of welded joints, to determine the optimal modes of thermomechanical treatment and to provide the necessary parameters for suitability of products in medical application.

The authors believe that optimizing the parameters of the modes of laser welding of the shape memory $\mathrm{Ti}_{49.4} \mathrm{Ni}_{50.6}$ alloy should be carried out with the change of the parameters in the following ranges: welding speeds are $500-5000 \mathrm{~mm} / \mathrm{min}$, value of focus change is $-1-+7 \mathrm{~mm}$, power of laser radiation is $200-400$ Watts.

\section{CONCLUSION}

Based on the results of analysis of the current state of research works on the subject of investigations, the perspective approaches to laser welding of flat samples of $\mathrm{Ti}-\mathrm{Ni}$ materials with the shape memory effect were selected.

The results of the project allowed determining the range of values in which it is expedient to optimize the parameters of laser treatment methods and which will be used in the future for development of technologies for laser welding of $\mathrm{Ti}-\mathrm{Ni}$ superelastic materials with the shape memory effect during manufacture of aortic valve frames, which should be widely implemented in the medical practice of Ukraine, which will contribute to obtaining a significant social and economic effect from the significant import substitution of this product.

It was determined that it is expedient to optimize the parameters of modes of laser welding of $\mathrm{Ti}-\mathrm{Ni}$ materials with the shape memory effect changing the parameters in the following ranges: value of the change in the position of the focal length of the lens $-1-+7 \mathrm{~mm}$, relative to the surface of welded parts, welding speed $500-5000 \mathrm{~mm} / \mathrm{min}$, power of laser radiation 200-400 Watts.

The final conclusions about the selection of the necessary parameters of the technological modes will be made after a series of tests and investigations planned at the next stage of the project fulfilment.

\section{REFERENCES}

1. T. Morris, The Matter of the Heart: a History of the Heart in Eleven Operations (New York City: Thomas Dunne Books: 2018).

2. B. Iung and A. Vahanian, Nature Reviews Cardiology, 8: 162 (2011).

3. C. Fauvel, R. Capoulade, E. Durand, D. M. Béziau, J. J. Schott, T. Le Tourneau, and H. Eltchaninoff, Archives of Cardiovascular Diseases, 113, No. 3: 209 (2020).

4. A. M. Williams, A. A. Brescia, T. M. Watt, M. A. Romano, and S. F. Bolling, Progress in Cardiovascular Diseases, 62, No. 6: 473 (2019). 
5. J. L. Cox, N. Ad, K. Myers, M. Gharib, and R. C. Quijano, J. Thoracic and Cardiovascular Surgery, 130, No. 2: 520 (2005).

6. Sachie Inoue, Koichi Nakao, Michiya Hanyu, Kentaro Hayashida, Hidetoshi Shibahara, Makoto Kobayashi, Miyoshi Asaoka, Kazuhiko Nishikawa, Seth Clancy, Jun Koshiishi, and Hiroyuki Sakamaki, Value in Health Regional Issues, 21: 82 (2020).

7. B. Iung, G. Baron, E. G. Butchart, F. Delahaye, C. Gohlke-Bärwolf, O. W. Levang, P. Tornos, J.-L. Vanoverschelde, F. Vermeer, E. Boersma, Ph. Ravaud, and A. Vahanian, European Heart J., 24, No. 13: 1231 (2003).

8. Price List Health Care Services Provided to Patients of LLC 'Clinic of New Technologies', http://www.cnt-amosov.com.ua/price.ukr.php

9. B. A. Carabello and W. J. Paulus, Lancet, 373, No. 9667: 956 (2009).

10. J. K. Forrest, Yale J. Biology and Medicine, 85: 239 (2012).

11. M. Thomas, G. Schymik, T. Walther, D. Himbert, T. Lefèvre, H. Treede, H. Eggebrecht, P. Rubino, I. Michev, R. Lange, W. N. Anderson, and O. Wendler, Circulation, 122, No. 1: 62 (2010).

12. N. Piazza, E. Grube, U. Gerckens, A. Linke, O. Luha, A. Ramondo, G. Ussia, P. Wenaweser, S. Windecker, J. C. Laborde, P. de Jaegere, and P. W. Serruys, EuroIntervention, 4, No. 2: 242 (2008).

13. L. Buellesfeld, P. Wenaweser, U. Gerckens, R. Mueller, B. Sauren, G. Latsios, B. Zickmann, G. Hellige, S. Windecker, and E. Grube, European Heart J., 31, No. 8: 984 (2010).

14. C. V. Bourantas N. M. van Mieghem, V. Farooq, O. I. Soliman, S. Windecker, N. Piazza, and P. W. Serruys, Int. J. Cardiology, 168, No. 1: 11 (2013).

15. E. A. Ovcharenko and I. I. Grekov, Bulletin of Surgery, 173, No. 5: 86 (2014) (in Russian).

16. V. E. Gyunter, V. I. Itin, L. A. Monasevich, Yu. I. Paskal et al., Effekty Pamyati Formy i Ikh Primenenie v Meditsine [Shape Memory Effects of and their Use in Medicine] (Novosibirsk: Nauka: 1992) (in Russian).

17. V. E. Gunter, V. N. Khodorenko, T. L. Chekalkin, and V. N. Olesova, Meditsinskie Materialy i Implantaty s Pamyatyu Formy [Medical Shape Memory Materials and Implants] (Tomsk: Publishing House of the International Information Centre: 2011), vol. 1 (in Russian).

18. J. Shaw and S. Kyriakides, J. Mechanics and Physics of Solids, 43, No. 8: 1243 (1995).

19. V. A. Lokhov, Yu. I. Nyashin, and A. G. Kuchumov, Russian J. Biomechanics, 11, No. 3: 9 (2007) (in Russian).

20. C. Kleinstreuer, Z. Li, C. A. Basciano, S. Seelecke, and M. A. Farber, J.Biomechanics, 41, No. 11: 2370 (2008).

21. W. Yan, C. H. Wang, X. P. Zhang, and Y. W. Mai, Smart Mater. Struct., 11: 947 (2002).

22. I. Vesely, J. Heart Valve Disease, 19: 543 (2010).

23. V. E. Gunther, Materialy s Pamyatyu Formy i Novye Tekhnologii v Meditsine [Shape Memory Materials and New Technologies in Medicine] (Tomsk: International Information Centre: 2007) (in Russian).

24. R. Zhuk, M. Anyakin, P. Kondrashev, O. Stepura, A. Muckhoid, and V. Kovalenko, Proc. of $26^{\text {th }}$ International Congress on Applications of Lasers and Electro-Optics ICALEO 2007 (October 29-November 1, 2007, Orlando) (Melville: 2007), p. 551. 
25. V. D. Shelyagin, A. V. Bernatskyi, O. M. Berdnikova, V. M. Sydorets, O. V. Siora, and S. G. Gryhorenko, Metallofiz. Noveishie Tekhnol., 42, No. 3: 363 (2020) (in Ukrainian).

26. V. D. Poznyakov, L. I. Markashova, V. D. Shelyagin, S. L. Zhdanov, A. V. Bernats'kyi, O. M. Berdnikova, and V. M. Sydorets, Strength Mater., 51: 843 (2019).

27. V. Shelyagin, V. Khaskin, A. Bernatskyi, A. Siora, V. Sydorets, and D. Chinakhov, Mater. Sci. Forum, 927: 64 (2018).

28. A. V. Bernatskyi, O. M. Berdnikova, I. M. Klochkov, V. M. Sydorets, and D. A. Chinakhov, IOP Conference Series: Materials Science and Engineering, 582: 012048 (2019).

29. O. V. Siora and A. V. Bernatsky, Metallofiz. Noveishie Tekhnol., 33: 569 (2011) (in Russian).

30. L. Markashova, O. Berdnikova, A. Bernatskyi, V. Sydorets, and O. Bushma. IOP Conference Series: Earth and Environmental Science, 224: 012013 (2019).

31. A. I. Lotkov, Yu. N. Koval, V. N. Grishkov, D. Yu. Zhapova, V. N. Timkin, and G. S. Firstov, Inorg. Mater. Appl. Res., 6: 498 (2015).

32. G. S. Firstov, R. G. Vitchev, H. Kumar, B. Blanpain, and J. Van Humbeeck, Biomaterials, 23: 4863 (2002).

33. Yu. M. Koval, R. Ya. Musienko, V. M. Slipchenko, T. G. Sych, S. M. Kedrovsky, and D. M. Kaleko, Metallofiz. Noveishie Tekhnol., 37, No. 10: 1339 (2015) (in Ukrainian).

34. S. Kedrovsky, Yu. Koval, V. Slipchenko, E. Slipchenko, and A. Filatov, Metallofiz. Noveishie Tekhnol., 37, No. 2: 199 (2015) (in Russian). 